\section{Study on hydroxyurea response in hemoglo- binopathies patients using genetic markers and liquid erythroid cultures}

\author{
Serena Sclafani, Alice Pecoraro, \\ Veronica Agrigento, Antonio Troia, \\ Rosario Di Maggio, Massimiliano Sacco, \\ Aurelio Maggio, Elena D'Alcamo, \\ Rosalba Di Marzo \\ Department of Oncology and \\ Hematology, U.O.C. Hematology for Rare \\ Blood and of Hematopoietic Organs \\ Diseases, A.O. Reunited Hospitals Villa \\ Sofia-Cervello, Palermo, Italy
}

\section{Abstract}

Increased expression of fetal hemoglobin ( $\mathrm{HbF})$ may ameliorate the clinical course of hemoglobinopathies. Hydroxyurea (HU) is the only inducer approved for the treatment of these diseases able to stimulate $\mathrm{HbF}$ production but patients' response is highly variable indicating the utility of the identification of pharmacogenomic biomarkers in order to predict pharmacological treatment efficacy. To date few studies to evaluate the role of genetic determinants in $\mathrm{HU}$ response have been conducted showing contradictory results. In this study we analyzed BCL11A, GATA-1, KLF-1 genes and $\gamma$-globin promoter in 60 alleles from 30 hemoglobinopathies patients under $\mathrm{HU}$ treatment to assess the role of these markers in $\mathrm{HU}$ response. We did not find any association between these genetic determinants and HU response. Before treatment started, the same patients were analyzed in vitro using liquid erythroid cultures in a test able to predict their response to HU. The results of our analysis confirm the absence of pharmacogenomic biomarker associated to $\mathrm{HU}$ response indicating that, the quantification of $\gamma$-globin mRNA fold increase remains the only method able to predict in vivo patients response to the drug.

\section{Introduction}

Hemoglobinopathies are inherited disorders characterized by anomalies of structure, function or production of globin chains that lead to a low or absent production of hemoglobin $(\mathrm{Hb})$ with a consequent wide clinical and phenotypic heterogeneity. ${ }^{1}$ Increased expression of fetal $\mathrm{Hb}(\mathrm{HbF})$ during adult life may ameliorate the clinical course of these disorders. In sickle cell disease (SCD), the beneficial effects of $\mathrm{HbF}$ are the inhibition of sickle $\mathrm{Hb}(\mathrm{HbS})$ polymerization, and dilution of the $\mathrm{HbS}$ concentration in the red blood cells while in $\beta$-thalassemia, $\gamma$ globin chains can substitute for $\beta$-globin chains and prevent the excess of $\alpha$-globin chains from damaging the red blood cells membrane. ${ }^{1}$ Multiple pharmacological agents able to increase $\mathrm{HbF}$ production have been investigated and hydroxyurea (HU) is the only inducer approved for the treatment of adult patients affected by sickle cell disease ${ }^{2}$ which entered into clinical practice for $\beta$-thalassemia intermedia $(\beta$-TI $) .{ }^{3}$ However, there is a great variability in the response of patients after $\mathrm{HU}$ therapy, in fact some patients are good responders while others exhibit little or no change in HbF levels. ${ }^{4,5}$ Moreover, in responder patients, a decrease in the efficacy during long-term treatment was observed. ${ }^{6,7}$

Liquid erythroid cultures, a system reproducing erythropoiesis in vitro, are a useful model to study human erythroid cells. It was previously shown that the $\gamma$-globin mRNA fold increase in cultured erythroid progenitors exposed to $\mathrm{HU}$, correlates to the in vivo $\mathrm{HbF}$ fold increase observed in patients after $\mathrm{HU}$ therapy. ${ }^{6}$ This approach is used as an in vitro test, the only current method able to predict in vivo patients response to the drug.

Several genetic factors can influence the severity of haemoglobinopathies; some of them act by reducing the degree of $\alpha / \beta$ imbalance (co-inheritance of $\alpha$-thalassemia) while others act by increasing $\mathrm{HbF}$ levels.

There is a broad range of basal HbF levels among individuals; single nucleotide polymorphisms (SNPs) or deletions within the beta globin cluster account for a portion of this variation. Moreover genetic studies are being done to detect the determinants influencing $\mathrm{HbF}$ levels by trans-acting factors not linked to the $\beta$-globin cluster. Genome-wide association studies (GWAS) have identified quantitative trait loci (QTLs) that affect baseline HbF levels in patients with $\mathrm{Hb}$ disorders. Several SNPs in these loci seem to be responsible for an estimated 15 to $20 \%$ of individual variation in $\mathrm{HbF}$ levels. ${ }^{8} \mathrm{~A}$ well-known HbF QTL is the XmnI polymorphism (rs7482144), a C T substitution at position -158 of the $\mathrm{G} \gamma$ globin gene promoter. ${ }^{9}$ Early reports and GWAS studies show that the presence of the XmnI T allele correlates with higher $\mathrm{HbF}$ levels in $\beta$-thalassemia and SCD patients. ${ }^{10-12}$

Another HbF QTL is the BCL11A gene, that codify for a $\gamma$-globin gene repressor. ${ }^{13}$ Several GWAS studies have associated SNPs in intron 2 of the BCL11A gene (e.g. rs11886868 and rs4671393) with higher HbF levels in patients with hemoglobinopathies. ${ }^{12,14}$ In particular, a strong association between rs11886868 and $\mathrm{HbF}$ level was highlighted in the Sardinian population. ${ }^{15}$ High HbF levels have been also
Correspondence: Alice Pecoraro, Department of Oncology and Hematology, U.0.C. Hematology for Rare Blood and of Hematopoietic Organs Diseases, A.O. Reunited Hospitals Villa SofiaCervello, 180, 90146 Palermo Italy.

Tel: +39.091.6802744. Fax: +39.091 .6880828 .

E-mail: a.pecoraro@ospedaliriunitipalermo.it

Key words: Hydroxyurea; Hemoglobinopathies; Genetic markers; Liquid erythroid cultures.

Contributions: SS and AP conducted the study and drafted the manuscript. SS and AP contributed equally. VA and AT performed the laboratory works and collected data. RDM recruited patients and collected clinical data. MS performed the statistical analysis. AM coordinated the study. ED and RD designed the study and edited the manuscript. ED and RD contributed equally.

Conflict of interest: he authors declare no potential conflict of interest.

Funding: this study was partially supported by Assessorato Sanità Regione Sicilia (Project n. T2012/4) and Fondazione Franco e Piera Cutino.

Received for publication: 5 July 2016 .

Accepted for publication: 11 October 2016.

This work is licensed under a Creative Commons Attribution-NonCommercial 4.0 International License (CC BY-NC 4.0).

(C) Copyright S. Sclafani et al., 2016

Licensee PAGEPress, Italy

Hematology Reports 2016; 8:6678

doi:10.4081/hr.2016.6678

associated with rs4671393 SNP (A/A genotype) in two different SCD cohorts (African American Cooperative Study of Sickle Cell Disease and SCD cohort from Brazil). ${ }^{12}$

Biological variability in $\mathrm{HbF}$ levels is also influenced by genes involved in $\gamma$-globin gene expression such as KLF-1 and GATA-1. Certain mutations within the $K L F-1$ transcription factor gene result in persistent high-level of $\mathrm{HbF}$ (HPFH) after birth. ${ }^{16}$ In a Maltese family a single mutation located in $K L F-1$ exon 2 (K288X) causing HPFH was shown to produce the lack of a DNA binding domain. ${ }^{17}$

Moreover the identification of a mutation in GATA-1 gene (R216W) in a child affected by congenital erythropoietic porphyria and $\beta$-thalassemia showing increased $\mathrm{HbF}$ level, suggests also an important role for GATA-1 in globin chain switching. ${ }^{18}$

The identification of pharmacogenomic biomarkers is important to predict pharmacological treatment efficacy. To date few studies have been conducted to evaluate the role of the genetic determinants in $\mathrm{HU}$ response.

Some studies have shown an association between the XmnI T/T and BCL11A rs 766432 
markers and response to HU. ${ }^{14,19,20}$ Conversely, other studies have failed to detect the correlation between XmnI genotype and $\mathrm{HU}$ response. ${ }^{21-23}$

The aim of this study was to analyze BCL11A, GATA-1, KLF-1 genes and $\gamma$-globin promoter in 60 alleles from 30 hemoglobinopathies patients to assess if there is a significant association between these genetic determinants and the efficacy of HU treatment. Furthermore in the same patients the response to $\mathrm{HU}$ was evaluated in vitro in a liquid erythroid culture system.

\section{Materials and Methods}

\section{Cohort description}

Thirty patients (12 males and 18 females) affected by SCD and thalassemia ( $1 \beta \mathrm{S} / \beta \mathrm{S}$ patient, $14 \beta S / \beta$-thalassemia patients and 15 $\beta$-TI patients) were studied. Molecular studies for genotype detection were performed according to procedures reported elsewhere. ${ }^{24}$ The patients characteristics are shown in Table 1. All the patients were treated with hydroxyurea. The mean dosage of $\mathrm{HU}$ administered was 16.4 $\mathrm{mg} / \mathrm{kg}$ (range 9.2-21), and the mean follow-up time was 111 months (range 5-180).

\section{Genotyping}

Peripheral blood in ethylene diamine tetraacetic acid-containing (EDTA) collection tubes was used to extract genomic DNA (standard phenol-cloroform method). DNA was amplified using the polymerase chain reaction (PCR): PCR mix $(50 \mu \mathrm{L})$ contained $200 \mathrm{ng}$ of genomic DNA, $1.5 \mu \mathrm{L}$ of 10 pmol primers, $5 \mu \mathrm{L}$ of buffer $10 \times, 1.5 \mu \mathrm{L}$ of $\mathrm{MgCl}_{2} 50 \mathrm{mmol}, 1 \mu \mathrm{L}$ of $40 \mathrm{mmol}$ dNTP and 2.5 U of Taq polymerase enzyme (Invitrogen Corp., Carlsbad, CA, USA). PCR products were analyzed on SYBR-Safe $3 \%$ agarose gel and displayed to the ultraviolet lamp. PCR products were sequenced bidirectional directly using Big-Dye terminator 3.1 cycle sequencing kit and run on ABI PRISM 3130 DNA analyzer (Applied Biosystems, Foster City, CA). Primers used for PCR and sequencing were designed in our laboratory (Table 2). Mutations in KLF-1 were detected by DNA sequencing of exon 2; mutations of $B C L 11 A$ were found by sequencing of the 5 exons and the two intronic regions containing SNP rs 11886868 and rs4671393. For the analysis of GATA1 gene the entire codifying region (6 exons) was sequenced. Also the XmnI genotype was obtained by XmnI enzymatic restriction. The PCR conditions will be made available upon request.

\section{Two phase liquid primary erythroid cultures}

After informed consent was obtained, $20 \mathrm{~mL}$ of peripheral blood was withdrawn from 30 patients before HU treatment. Primary cell cultures were performed as previously described. ${ }^{25}$ Mononuclear cells from peripheral blood were isolated by centrifugation over Ficoll-Hypaque (1.077 g/mL; GE Healthcare Bio-Sciences AB, Uppsala, Sweden) at $1200 \times \mathrm{g}$ for $15 \mathrm{~min}$. The nucleated cells were first cultured in a minimal essential medium (MEM) supplemented with $1 \mu \mathrm{g} / \mathrm{mL}$ cyclosporine A (Novartis Basilea, Switzerland), 10\% fetal calf serum (FCS, Invitrogen, Carlsbad, California, USA) and $10 \%$ conditioned medium collected from cultures of the human bladder carcinoma 5637 cell line. After 6 days of incubation in phase I culture, the non-adherent cells were harvested, washed, and resuspended in phase II medium composed of $\alpha$-MEM, 30\% FCS, $1 \%$ deionized bovine serum albumin (SigmaAldrich, St. Louis, Missouri, USA), 10 mM 2mercapto-ethanol (Sigma), $1.5 \mathrm{mM}$ glutamine (Euroclone), $1 \mathrm{mM}$ dexamethasone (Laboratorio Farmacologico Milanese, MI, Italy), $1 \mathrm{U} / \mathrm{mL}$ recombinant erythropoietin (Janssen-Cilag, Leiden, The Netherlands), 10 $\mathrm{ng} / \mathrm{mL}$ Stem Cell Factor (Sigma), and 0.3 $\mathrm{mg} / \mathrm{mL}$ human holo-transferrin (Sigma). Cells were harvested at day 10 of phase II culture. We performed at least two different primary cultures for each patient.

\section{Hydroxyurea treatment in vitro}

At day 6 of phase II, cells were washed with $\alpha$-MEM, and the cell culture was split. Half of the culture was exposed to $100 \mu \mathrm{M} \mathrm{HU}$ (Teofarma Srl, Pavia, Italy), a dose that corresponds to the serum HU concentration during in vivo treatment at $20 \mathrm{mg} / \mathrm{kg} / \mathrm{day}^{26}$ As a control, the other half of the culture was grown without the drug. At day 10, the cells were harvested and analyzed. At the $100 \mu \mathrm{M}$ HU dosage, erythroid progenitors express the maximum potential of $\gamma$-mRNA expression, in that, when lower concentrations were tested $(75 \mu \mathrm{M})$, the same $\gamma$-mRNA increase was obtained. Higher doses cause the cell death.

\section{Flow cytometric analysis}

The phase II cultured cells were monitored for erythroid differentiation by measuring cellular expression of transferrin receptor (CD71PE) (Immunotech, Marseille Cedex 9, France) and glycophorin A antigen (GPA-FITC) (Immunotech) as previously described. ${ }^{27}$ Cells were analyzed using the Cytomics FC 500 (Beckman Coulter Inc., Fullerton, CA 92835).

\section{Real-time quantitative polymerase chain reaction}

RNA was isolated with TRIzol® reagent (Invitrogen, Carlsbad CA 92008, USA) according to manufacturer's instructions. cDNA synthesis was carried out using High Capacity cDNA Reverse Transcription kit (Applied
Biosystems) from $1 \mu \mathrm{g}$ of total RNA. Quantitative real-time PCR assay of transcripts was then performed with the use of gene-specific double fluorescently-labeled probes in a 7900 Sequence Detector (Applied Biosystems, Norwalk, CT). All samples were assayed using TaqMan Universal PCR Master Mix (Applied Biosystems Foster City, CA, USA). The following primer and probe sequences were used: $\gamma$-globin forward primer, $5^{\prime}$ GGCAACCTGTCCTCTGCCTC-3'; $\gamma$-globin reverse primer, 5'-GAAATGGATTGCCAAAACGG-3'; $\gamma$-globin probe, $5^{\prime}$-FAMCAAGCTCCTGGGAAATGTGCTGGTG-TAMRA$3^{\prime}{ }^{27}$ As endogenous control the human glyceraldehyde-3-phosphate dehydrogenase gene $(G A P D H)$ (Pre-Developed Taqman assay control kit, Applied Biosystem) was used. The comparative threshold cycle $(\mathrm{Ct})$ method was used to determine the difference $(\mathrm{Ct})$ between the $\mathrm{Ct}$ of treated samples and the $\mathrm{Ct}$ of the untreated samples. Before subtraction, the $\mathrm{Ct}$ was normalized by the $\mathrm{Ct}$ of the endogenous reference gene, GAPDH. The experiments were performed in triplicate to ensure the reproducibility of results.

\section{Statistical analysis}

Data are presented as mean \pm SD. $\chi$ square test was used to assess if there is statistical significance of the differences in the frequency of genetic variants among the hemoglobinopathies groups analyzed. $\mathrm{R}$ software and Microsoft Excel were used for the statistical analysis.

\section{Results}

Primary erythroid cultures from peripheral blood hematopoietic stem cells of 30 patients (15 SCD and $15 \beta$-TI) were performed. Flow cytometric analysis of erythroid markers (CD71 and GPA) did not show any difference during erythroid differentiation between cultures derived from HU responder and nonresponder patients. For each sample, the effect of HU in terms of $\gamma$-globin mRNA fold increase respect to untreated cells was measured by mRNA relative quantification using a fluorescence-based quantitative real-time PCR assay. At least two different primary cultures for each sample were performed. The results of this analysis, predictive of patients' response to $\mathrm{HU}$ treatment, have been summarized in Table 1 . After the in vitro study, all the patients started $\mathrm{HU}$ treatment in vivo. Nine $\beta$-TI patients attained an increase of their transfusion interval while 6 of them stopped the treatment since they did not show an increase in $\mathrm{Hb}$ or an appreciable change in blood transfusion intervals. In SCD patients HU treatment determined increase in $\mathrm{HbF}$ and total $\mathrm{Hb}$ and 
decrease in white blood cell counts. Moreover a reduction of vaso-occlusive crisis, acute chest syndromes and the other complications of the disease were observed. Only 1 SCD patient did not respond and stopped the treatment. After one to two years of treatment, when the in vivo response was stabilized, $\mathrm{HbF}$ fold increase was calculated and compared to $\gamma$-globin mRNA fold increase measured in vitro. For all patients a very good correlation between the in vivo and the in vitro $\mathrm{HU}$ response was observed (Pearson correlation $=0.95, \mathrm{P}=0.05)$. In fact, in all patients studied, the in vitro $\gamma$-globin mRNA fold increase was very similar to the in vivo $\mathrm{HbF}$ fold increase confirming the predictive value of the in vitro test. All the patients were studied for the presence of some genetic determinants responsible of high level of fetal hemoglobin production (BCL11A, -158 $\gamma$-globin gene promoter, GATA-1 and KLF-1). Genotyping results are summarized in Table 1. No association between these genetic markers and $\mathrm{HU}$ response was found. Moreover, in exon 2 of BCL11A gene of 1 patient (n. 14) a new mutation (L45R/N) not previously described was detected. This mutation does not appear to be associated to HU response since the patient's brother (n. 13) that presents the same thalassemia genotype $(\beta 039 / \delta \beta)$, the same basal $\mathrm{HbF}$ level and the same response to $\mathrm{HU}$ treatment does not show the mutation.

A not previously described T insertion located 74 bp downstream to rs11886868 SNP of $B C L 11 A$ gene was identified always associated to the T allele.

The XmnI polymorphism was found in heterozygous only in two responder patients (n. 3 and $\mathrm{n}$. 18) while R216W mutation in the exon 4 of $G A T A-1$ gene and K288X in KLF-1 gene were not found in any patient. A point mutation in exon 2 of $K L F-1$ gene causing the aminoacid substitution F182L (c.544T >C) was found in heterozygous in 3 patients.

\section{Discussion and Conclusions}

Hemoglobinopathies, such as SCD and thalassemia are among the most common human genetic disorders. HbF increase is of enormous clinical relevance given its role in ameliorating the severity of these diseases. Among the pharmacological agents able to induce $\mathrm{HbF}$ production, $\mathrm{HU}$ is the drug of choice for the treatment of hemoglobinopathies but patients' response to this drug varies considerably. For this reason the ability to predict $\mathrm{HbF}$ response to $\mathrm{HU}$ treatment would be helpful for the selection of responders to prevent potential adverse drug reactions in non-responder patients.

The regulation of $\mathrm{HbF}$ level is complex and involves elements and factors cis- and transacting to the $\beta$-globin cluster such as $-158 \gamma$ globin gene promoter, KLF-1, BCL11A, GATA-1 and probably other regulatory loci; epigenetic and cellular factors could also have regulatory

Table 1. Genotyping results and correlation between in vitro and in vivo response.

\begin{tabular}{|c|c|c|c|c|c|c|c|c|c|c|}
\hline ID & Gender & Ir Genotype & $\begin{array}{r}\text { BCL11A } \\
\text { rs11 }\end{array}$ & $\begin{array}{l}671393 \\
868\end{array}$ & BCL11A & KLF-1 & -158 & GATA-1 & $\begin{array}{l}\gamma \text {-globin mRNA } \\
\text { increase }\end{array}$ & $\begin{array}{l}\text { In vivo } \\
\text { response }\end{array}$ \\
\hline 1 & M & IVSI, 110/-87 & $\mathrm{G} / \mathrm{G}$ & $\mathrm{T} / \mathrm{T}+$ ins & w.t. & $\mathrm{F} 182 \mathrm{~L} / \mathrm{N}$ & $\mathrm{C} / \mathrm{C}$ & w.t. & $1.3 \pm 0.2$ & YES (1.24 fold increase) \\
\hline 2 & $\mathrm{~F}$ & IVS I,1/-101 & $\mathrm{A} / \mathrm{G}$ & $\mathrm{C} / \mathrm{C}$ & w.t. & w.t. & $\mathrm{C} / \mathrm{C}$ & w.t. & $1.2 \pm 0.2$ & NO (1.29 fold increase) \\
\hline 3 & $\mathrm{~F}$ & IVS I,6/IVS I,6 & $\mathrm{G} / \mathrm{G}$ & $\mathrm{T} / \mathrm{T}+\mathrm{ins}$ & w.t. & w.t. & $\mathrm{T} / \mathrm{C}$ & w.t. & $1.5 \pm 0.1$ & YES (1.31 fold increase) \\
\hline 4 & $\mathrm{M}$ & IVS I,6/IVS I,6 & $\mathrm{A} / \mathrm{A}$ & $\mathrm{C} / \mathrm{C}$ & w.t. & w.t. & $\mathrm{C} / \mathrm{C}$ & w.t. & $1.5 \pm 0.2$ & NO (1.69 fold increase) \\
\hline 5 & M & IVS I,6/IVS I,6 & $\mathrm{A} / \mathrm{G}$ & $\mathrm{C} / \mathrm{T}+\mathrm{ins}$ & w.t. & w.t. & $\mathrm{C} / \mathrm{C}$ & w.t. & $3 \pm 0.1$ & NO (2.68 fold increase) \\
\hline 6 & $\mathrm{~F}$ & IVS I,6/IVS I,6 & $\mathrm{A} / \mathrm{G}$ & $\mathrm{C} / \mathrm{T}+\mathrm{ins}$ & w.t. & w.t. & $\mathrm{C} / \mathrm{C}$ & w.t. & $2 \pm 0$ & NO (2.3 fold increase) \\
\hline 7 & $\mathrm{M}$ & IVS I,6/IVS I,6 & $\mathrm{A} / \mathrm{G}$ & $\mathrm{C} / \mathrm{T}+\mathrm{ins}$ & w.t. & w.t. & $\mathrm{C} / \mathrm{C}$ & w.t. & $2 \pm 0$ & NO (2.15 fold increase) \\
\hline 8 & $\mathrm{~F}$ & $\beta 039 /$ IVS I, 6 & $\mathrm{G} / \mathrm{G}$ & $\mathrm{C} / \mathrm{T}+\mathrm{ins}$ & w.t. & w.t. & $\mathrm{C} / \mathrm{C}$ & w.t. & $1.8 \pm 0.1$ & YES (1.59 fold increase) \\
\hline 9 & $\mathrm{~F}$ & $\beta 039 /$ IVS I, 6 & $\mathrm{~A} / \mathrm{A}$ & $\mathrm{C} / \mathrm{C}$ & w.t. & w.t. & $\mathrm{C} / \mathrm{C}$ & w.t. & $1 \pm 0.2$ & NO (1.10 fold increase) \\
\hline 10 & M & $\beta 039 /$ IVS I, 6 & $\mathrm{~A} / \mathrm{A}$ & $\mathrm{C} / \mathrm{C}$ & w.t. & w.t. & $\mathrm{C} / \mathrm{C}$ & w.t. & $1 \pm 0.2$ & YES (1.20 fold increase) \\
\hline 11 & M & $\beta 039 /$ IVS I, 6 & $\mathrm{~A} / \mathrm{G}$ & $\mathrm{C} / \mathrm{T}+\mathrm{ins}$ & w.t. & w.t. & $\mathrm{C} / \mathrm{C}$ & w.t. & $1.8 \pm 0.2$ & YES (1.57 fold increase) \\
\hline 12 & $\mathrm{M}$ & $\beta$ Lepore//Lepore & e $\quad \mathrm{G} / \mathrm{G}$ & $\mathrm{C} / \mathrm{T}+\mathrm{ins}$ & w.t. & w.t. & $\mathrm{C} / \mathrm{C}$ & w.t. & $1.8 \pm 0.3$ & YES (1.58 fold increase) \\
\hline 13 & M & $\delta \beta / \beta 039$ & $\mathrm{~A} / \mathrm{A}$ & $\mathrm{C} / \mathrm{C}$ & w.t. & w.t. & $\mathrm{C} / \mathrm{C}$ & w.t. & $1.4 \pm 0.2$ & YES (1,15 fold increase) \\
\hline 14 & $\mathrm{~F}$ & $\delta \beta / \beta 039$ & $\mathrm{~A} / \mathrm{G}$ & $\mathrm{C} / \mathrm{T}+\mathrm{ins}$ & L45R/N & w.t. & $\mathrm{C} / \mathrm{C}$ & w.t. & $1.3 \pm 0.2$ & YES (1.29 fold increase) \\
\hline 15 & $\mathrm{~F}$ & $\operatorname{cod} 6 / \beta 039$ & $\mathrm{~A} / \mathrm{G}$ & $\mathrm{C} / \mathrm{T}+\mathrm{ins}$ & w.t. & F182L/N & $\mathrm{C} / \mathrm{C}$ & w.t. & $1 \pm 0$ & YES (1.17 fold increase) \\
\hline 16 & M & $\beta S / \beta 039$ & $\mathrm{G} / \mathrm{G}$ & $\mathrm{T} / \mathrm{T}+\mathrm{ins}$ & w.t. & w.t. & $\mathrm{C} / \mathrm{C}$ & w.t. & $1.3 \pm 0.2$ & YES (1.5 fold increase) \\
\hline 17 & $\mathrm{~F}$ & $\beta S / \beta 039$ & $\mathrm{~A} / \mathrm{G}$ & $\mathrm{C} / \mathrm{T}+\mathrm{ins}$ & w.t. & w.t. & $\mathrm{C} / \mathrm{C}$ & w.t. & $2.7 \pm 0.3$ & YES (3 fold increase) \\
\hline 18 & M & $\beta S / \beta 039$ & $\mathrm{G} / \mathrm{G}$ & $\mathrm{T} / \mathrm{T}+$ ins & w.t. & w.t. & $\mathrm{T} / \mathrm{C}$ & w.t. & $1.2 \pm 0.2$ & YES (1.06 fold increase) \\
\hline 19 & $\mathrm{~F}$ & $\beta \mathrm{S} / \beta 039$ & $\mathrm{~A} / \mathrm{G}$ & $\mathrm{C} / \mathrm{C}$ & w.t. & F182L/N & $\mathrm{C} / \mathrm{C}$ & w.t. & $1.7 \pm 0.2$ & YES (1.85 fold increase) \\
\hline 20 & $\mathrm{~F}$ & $\beta S / \beta 039$ & $\mathrm{~A} / \mathrm{G}$ & $\mathrm{C} / \mathrm{T}+\mathrm{ins}$ & w.t. & w.t. & $\mathrm{C} / \mathrm{C}$ & w.t. & $1.4 \pm 0.1$ & YES (1.51 fold increase) \\
\hline 21 & $\mathrm{~F}$ & $\beta S / \beta 039$ & $\mathrm{G} / \mathrm{G}$ & $\mathrm{T} / \mathrm{T}+\mathrm{ins}$ & w.t. & w.t. & $\mathrm{C} / \mathrm{C}$ & w.t. & $2.2 \pm 0.3$ & YES (1.87 fold increase) \\
\hline 22 & $\mathrm{~F}$ & $\beta S / \beta 039$ & $\mathrm{G} / \mathrm{G}$ & $\mathrm{T} / \mathrm{T}+\mathrm{ins}$ & w.t. & w.t. & $\mathrm{C} / \mathrm{C}$ & w.t. & $3 \pm 0$ & YES (3.04 fold increase) \\
\hline 23 & M & $\beta S / I V S I, 110$ & $\mathrm{~A} / \mathrm{G}$ & $\mathrm{C} / \mathrm{C}$ & w.t. & w.t. & $\mathrm{C} / \mathrm{C}$ & w.t. & $2.5 \pm 0.2$ & YES (2.56 fold increase) \\
\hline 24 & $\mathrm{~F}$ & $\beta S / I V S I, 110$ & $\mathrm{~A} / \mathrm{A}$ & $\mathrm{C} / \mathrm{C}$ & w.t. & w.t. & $\mathrm{C} / \mathrm{C}$ & w.t. & $2.3 \pm 0.2$ & YES (2.83 fold increase) \\
\hline 25 & $\mathrm{~F}$ & $\beta S / I V S I, 110$ & $\mathrm{~A} / \mathrm{A}$ & $\mathrm{C} / \mathrm{C}$ & w.t. & w.t. & $\mathrm{C} / \mathrm{C}$ & w.t. & $1 \pm 0$ & YES (1,11 fold increase) \\
\hline 26 & $\mathrm{~F}$ & $\beta S / I V S I, 110$ & $\mathrm{G} / \mathrm{G}$ & $\mathrm{C} / \mathrm{T}+\mathrm{ins}$ & w.t. & w.t. & $\mathrm{C} / \mathrm{C}$ & w.t. & $1.6 \pm 0.2$ & YES (1.81 fold increae) \\
\hline 27 & $\mathrm{~F}$ & $\beta$ s/IVS II, 745 & $\mathrm{~A} / \mathrm{G}$ & $\mathrm{C} / \mathrm{T}+\mathrm{ins}$ & w.t. & w.t. & $\mathrm{C} / \mathrm{C}$ & w.t. & $1.7 \pm 0.2$ & NO (1.79 fold increase) \\
\hline 28 & M & $\beta S / \delta \beta$ & $\mathrm{A} / \mathrm{G}$ & $\mathrm{C} / \mathrm{T}+\mathrm{ins}$ & w.t. & w.t. & $\mathrm{C} / \mathrm{C}$ & w.t. & $1 \pm 0$ & YES (1.22 fold increase) \\
\hline 29 & M & $\beta S / \beta S$ & $\mathrm{G} / \mathrm{G}$ & $\mathrm{T} / \mathrm{T}+\mathrm{ins}$ & w.t. & w.t. & $\mathrm{C} / \mathrm{C}$ & w.t. & $1.2 \pm 0.1$ & YES (1.24 fold increase) \\
\hline 30 & $\mathrm{~F}$ & $\beta \mathrm{s} / \mathrm{IVS} \mathrm{I}, 5 \mathrm{c}$ & $\mathrm{G} / \mathrm{G}$ & $\mathrm{T} / \mathrm{T}+\mathrm{ins}$ & w.t. & w.t. & $\mathrm{C} / \mathrm{C}$ & w.t. & $1.3 \pm 0.2$ & YES (1.35 fold increase) \\
\hline
\end{tabular}


Table 2. Primer used for amplification and detection of the single nucleotide polymorphisms and alleles.

\begin{tabular}{|c|c|c|}
\hline Allele & Transcription & Primers sequence $\left(5^{\prime}<3^{\prime}\right)$ \\
\hline rs 4671393 & $\begin{array}{l}\text { Forward } \\
\text { Reverse }\end{array}$ & $\begin{array}{l}\text { CACTAGCTCAGAAATGGACTT } \\
\text { ACCTTCCTTTAATCAGCTTCC }\end{array}$ \\
\hline rs 11886868 & $\begin{array}{l}\text { Forward } \\
\text { Reverse }\end{array}$ & $\begin{array}{c}\text { ATCAGATACAGAACACGTCC } \\
\text { GTCCATTGTAGCACTGTTCAT }\end{array}$ \\
\hline KLF-1 exon 2b & $\begin{array}{l}\text { Forward } \\
\text { Reverse }\end{array}$ & $\begin{array}{l}\text { AGACTCTGGGCGCATATGCT } \\
\text { AGGAGGCACTCACTCTCAGA }\end{array}$ \\
\hline BCL11A exon 1 & $\begin{array}{l}\text { Forward } \\
\text { Reverse }\end{array}$ & $\begin{array}{c}\text { GGA TGT CAA AAG GCA CTG ATG } \\
\text { TCTCTTTTACCTCGACTCTCG }\end{array}$ \\
\hline BCL11A exon 2 & $\begin{array}{l}\text { Forward } \\
\text { Reverse }\end{array}$ & $\begin{array}{l}\text { TTACATGATGTGGTGGGATGG } \\
\text { GCTGTCATGGACAGTCACATA }\end{array}$ \\
\hline BCL11A exon 3 & $\begin{array}{l}\text { Forward } \\
\text { Reverse }\end{array}$ & $\begin{array}{l}\text { CTGGGAAATAACTCACCACTC } \\
\text { GCTGCCAAGTGAGTAATGGAA }\end{array}$ \\
\hline BCL11A exon 4 & $\begin{array}{l}\text { Forward } \\
\text { Reverse }\end{array}$ & $\begin{array}{l}\text { GGCTGGAGGTGGAACATAAAT } \\
\text { TCTCTCGATACTGATCCTGGT }\end{array}$ \\
\hline BCL11A exon 5 & $\begin{array}{l}\text { Forward } \\
\text { Reverse }\end{array}$ & $\begin{array}{l}\text { TCATGCTTAAGATGCCAGTGG } \\
\text { AAATAAAATGGCGCTGCAGGC }\end{array}$ \\
\hline GATA-1 exon 1 & $\begin{array}{l}\text { Forward } \\
\text { Reverse }\end{array}$ & $\begin{array}{l}\text { CAAGAGGTGCCCCACAAGCAT } \\
\text { GACACTTTGGGGACCAGCTGT }\end{array}$ \\
\hline GATA-1 exon 2 & $\begin{array}{l}\text { Forward } \\
\text { Reverse }\end{array}$ & $\begin{array}{l}\text { AGAAATATGGAGACTGAGGTG } \\
\text { ATCCTCACAGTGGTATTCTGA }\end{array}$ \\
\hline GATA-1 exon 3 & $\begin{array}{l}\text { Forward } \\
\text { Reverse }\end{array}$ & $\begin{array}{c}\text { TGTGGAGCTGGGAACTTG } \\
\text { TCAGCTCAGCTTTACTTTGGG }\end{array}$ \\
\hline GATA-1 exon 4 & $\begin{array}{l}\text { Forward } \\
\text { Reverse }\end{array}$ & $\begin{array}{l}\text { CCCTGTGGTGAGAAATTCAAA } \\
\text { GCAGTAGCTTCCTGTAATCAT }\end{array}$ \\
\hline GATA-1 exon 5 & $\begin{array}{l}\text { Forward } \\
\text { Reverse }\end{array}$ & $\begin{array}{l}\text { TTCAACCTGACCCTCACTTCT } \\
\text { GAGGTAGAACAGGAACAGAGT }\end{array}$ \\
\hline GATA-1 exon 6 & $\begin{array}{l}\text { Forward } \\
\text { Reverse }\end{array}$ & $\begin{array}{l}\text { TGAAAGAAGTGGGGTAGAGAG } \\
\text { AGAGAGCCACAGGCATTGTTA }\end{array}$ \\
\hline
\end{tabular}

roles. ${ }^{28}$ It is possible that these and also other genetic determinants modulate $\mathrm{HbF}$ response. The correlation of genetic determinants with high $\mathrm{HbF}$ levels after HU treatment was studied yielding contradictory results. In fact, although the presence of Xmn I polymorphism is more often associated with better response to HU therapy, ${ }^{19,20}$ other studies did not find any association of such polymorphism with high $\mathrm{HbF}$ levels upon $\mathrm{HU}$ treatment. ${ }^{22}$ In the present study, we examine the possible association of some HbF QTLs with the response to $\mathrm{HU}$ in 30 hemoglobinopathies patients. No association between these genetic markers and $\mathrm{HU}$ response is established, even if could be useful to extend this analysis to a larger cohort of patients to confirm these results. The response to $\mathrm{HU}$ therapy is complex and polymorphisms in many genes modulating $\gamma$-globin gene expression, HU metabolism and erythroid progenitor proliferation might affect patients' response. Statistically significant associations of $\mathrm{HbF}$ response to $\mathrm{HU}$ with multiple SNPs in several genes (ARG2, FLT1, HAO2, NOS1, KLF10, SALL2) have been reported. ${ }^{29,30}$ To date the use of genetic determinants to predict the effect of HU is still not possible. For this reason human liquid erythroid culture system, an efficacious but complex and time consuming approach, at the moment remains the only method able to predict patients' response to $\mathrm{HU}$.

Nevertheless recent advances in genomic analysis technologies, including next generation sequencing and microarrays will provide revolutionary opportunities allowing to analyze a large number of genes and patients simultaneously for the search of genetic determinants that could help to trace a genetic profile rather than single mutations that may be predictive of pharmacological response.

\section{References}

1. Steinberg MH, Forget BG, Higgs DR, Weatherall DJ. Disorders of hemoglobin, Cambridge, UK: Cambridge University Press; 2001.

2. Platt OS. Hydroxyurea for the treatment of sickle cell anemia. $\mathrm{N}$ Engl $\mathrm{J}$ Med 2008;358:1362-9.

3. Rigano P, Manfrè L, La Galla R, et al. Clinical and hematological response to hydroxyurea in a patient with $\mathrm{Hb}$ Lepore/bthalassemia. Hemoglobin 1997;21:219-26.

4. Fucharoen S, Siritanaratkul N, Winichagoon $\mathrm{P}$, et al. Hydroxyurea increases Hemoglobin F levels and improves the effectiveness of erythropoiesis in b-thalassemia/Hemoglobin E disease. Blood 1996;87:887-92.

5. Bradai M. Hydroxyurea can eliminate transfusion requirements in children with severe $\beta$-thalassemia. Blood 2003;102: 1529-30.

6. Pecoraro A, Rigano P, Troia A, et al. Quantification of HBG mRNA in primary erythroid cultures: prediction of the response to hydroxyurea in sickle cell and $\beta$-thalassemia. Eur J Haematol 2013;92: 66-72.

7. Rigano P, Pecoraro A, Calzolari R, et al. Desensitization to hydroxycarbamide following long-term treatment of thalassaemia intermedia as observed in vivo and in primary erythroid cultures from treated patients. Br J Haematol 2010;151:509-15.

8. Green NS, Barral S. Genetic modifiers of $\mathrm{HbF}$ and response to hydroxyurea in sickle cell disease. Pediatr Blood Cancer 2010;56: 177-81.

9. Labie D, Dunda-Belkhodja 0, Rouabhi F, et al. The -158 site $5^{\prime}$ to the $\mathrm{G} \gamma$ gene and $\mathrm{G} \gamma$ expression. Blood 1985;66:1463-5.

10. Gilman JG, Huisman TH. DNA sequence variation associated with elevated fetal $\mathrm{G} \gamma$ globin production. Blood 1985;66:783-7.

11. Labie D, Pagnier J, Lapoumeroulie C, et al. Common haplotype dependency of high $\mathrm{G} \gamma$-globin gene expression and high $\mathrm{Hb} \mathrm{F}$ levels in $\beta$-thalassemia and sickle cell anemia patients. Proc Natl Acad Sci USA 1985;82:2111-4.

12. Lettre G, Sankaran VG, Bezerra MAC, et al. DNA polymorphisms at the BCL11A, HBS1L-MYB, and $\beta$-globin loci associate with fetal hemoglobin levels and pain crises in sickle cell disease. Proc Natl Acad Sci USA 2008;105:11869-74.

13. Sankaran VG, Menne TF, $\mathrm{Xu}$ J, et al. Human fetal hemoglobin expression is regulated by the developmental stage specific repressor BCL11A. Science 2008;322:1839-42.

14. Banan M, Bayat H, Azarkeivan A, et al. The XmnI and BCL11A single nucleotide polymorphisms may help predict hydroxyurea response in Iranian $\beta$-thalassemia patients. Hemoglobin 2012;36:371-80.

15. Uda M, Galanello R, Sanna S, et al Genome-wide association study shows BCL11A associated with persistent fetal hemoglobin and amelioration of the phenotype of $\beta$-thalassemia. Proc Natl Acad Sci USA 2008;105:1620-5.

16. Guy LG, Mei Q, Perkins AC, et al Erythroid Kruppel-like factor is essential forbeta-globin gene expression even in absence of gene competition, but is not sufficient to induce the switch from gamma-globin to beta-globin gene expression. Blood 1998;91:2259-63. 
17. Borg J, Papadopoulos P, Georgitsi M, et al Haploinsufficiency for the erythroid transcription factor KLF1 causes hereditary persistence of fetal hemoglobin. Nat Genet 2010;42:801-5.

18. Phillips JD, Steensma DP, Pulsipher MA, et al Congenital erythropoietic porphyria due to a mutation in GATA1: the first trans-acting mutation causative for a human porphyria. Blood 2007;109:2618-21.

19. Alebouyeh M, Moussavi F, Haddad-Deylami $\mathrm{H}$, Vossough P. Hydroxyurea in the treatment of major $\beta$-thalassemia and importance of genetic screening. Ann Hematol 2004;83:430-3.

20. Yavarian M, Karimi M, Bakker E, et al. Response to hydroxyurea treatment in Iranian transfusiondependent $\beta$-thalassemia patients. Haematologica 2004;89:1172-8.

21. Bradai M, Pissard S, Abad MT, et al. Decreased transfusion needs associated with hydroxyurea therapy in Algerian patients with thalassemia major or inter- media. Transfusion 2007;47:1830-6.

22. Dixit A, Chatterjee TC, Mishra P, et al. Hydroxyurea in thalassemia intermedia- a promising therapy. Ann Hematol 2005;84:441-6.

23. Ehsani MA, Hedayati-Asl AA, Bagheri A, et al. Hydroxyurea-induced hematological response in transfusion-independent betathalassemia intermedia: case series and review of literature. Pediatr Hematol Oncol 2009;26:560-5.

24. Maggio A, Giambona A, Cai SP, et al. Rapid and simultaneous typing of hemoglobin $\mathrm{S}$, hemoglobin $\mathrm{C}$, and seven Mediterranean beta-thalassemia mutations by covalent reverse dot-blot analysis: application to prenatal diagnosis in Sicily. Blood 1993;81:239-42.

25. Di Marzo R, Acuto S, Calzolari R, Maggio A. Allele-specific transcription of fetal genes in primary erythroid cell cultures from Lepore and deltabeta degrees thalassemia patients. Exp Hematol 2005;33:1363-70.

26. Fabricius E, Rajewsky F. Determination of hydroxyurea in mammalian tissues and blood. Rev Eur Etud Clin Biol 1971;16:67983.

27. Calzolari R, Pecoraro A, Borruso V, et al. Induction of gamma-globin gene transcription by hydroxycarbamide in primary erythroid cell cultures from Lepore patients. Br J Haematol 2008;141:720-7.

28. Ngo DA, Steinberg MH. Genomic approaches to identifying targets for treating $\beta$ hemoglobinopathies. BMC Med Genom 2015;8:44.

29. Borg J, Phylactides M, Bartsakoulia M, et al. KLF10 gene expression is associated with high fetal hemoglobin levels and with response to hydroxyurea treatment in $\beta$ hemoglobinopathy patients. Pharmacogenom 2012;13:1487-500.

30. Sheehan VA, Crosby JR, Sabo A, et al. Whole exome sequencing identifies novel genes for fetal hemoglobin response to hydroxyurea in children with sickle cell anemia. PLoS One 2014;9:e110740. 